\title{
Childhood Infratentorial Ependymoma
}

National Cancer Institute

\section{Source}

National Cancer Institute. Childhood Infratentorial Ependymoma. NCI Thesaurus. Code C9041.

An ependymoma that arises from the infratentorial region of the brain and occurs during childhood. 